\title{
Hepatitis B Virus and $2 \beta$-Microglobulin Concentration in Individuals Living with Human Immune Deficiency Virus in South West Nigeria
}

\section{Abstract}

Hepatitis B virus (HBV) is a major health concern with people leaving with HIVIAIDS. However, not much have associated HBV with increase in $2 \beta$-microglobulin ( $2 \mathrm{MG}$ ) concentration in people living with HIV/ AIDS in sub-saharan Africa though is a tumor marker. Blood sample $(n=435)$ were collected from individuals attending various HIV screening centres in South west Nigeria after the exclusion of individuals testing positive to tuberculosis, Hepatitis C virus (HCV), Human papilloma virus (HPV), (all tested by ELISA technique) typhoid and malaria. Of the 435 individuals selected for the study, 110 were positive for HIV alone, 217 for HIV and HBV while 108 were mono-infected with $\mathrm{HBV}$. All individuals were tested for $2 \mathrm{MG}$ using the quantitative ELISA technique. There was a significant increase in $2 \mathrm{MG}$ concentration among those infected with HIV and HBV as opposed to the low levels in mono-infected individuals when compared to the normal concentration of $2 \mathrm{MG}$ in healthy individuals.

\section{Keywords}

2 Beta Microglobulin; Hepatitis B; Hiv; Tumour, Markers.

\section{Lawrence Okoror ${ }^{1}$}

1 Joseph Ayo Babalola University, IkejiArakeji, Osun State, Nigeria.

Contact information:

Lawrence Okoror.

” LEOkoror@gmail.com

\section{Introduction}

Hepatitis B virus (HBV) have been reported to affect over 350 miIlion people worldwide with hepatitis B surface antigen (HBsAg) associated with chronic infection. Hepatitis $B$ virus infection is one of the major health concern for people living with HIV/AIDS. And anti HBs seroconversion associated with best outcome in patients with HBV infection [1-3]. However, not much has associated HBV infection to $2-\beta$-microglobulin concentration in serum recently especially in sub-saharan Africa. 2- $\beta$-Microglobulin is a $11.7 \mathrm{KDa}$ nonglycosyla- 
ted protein comprising of 99 amino acids [4]. It is one of the major histocompatibility complex class molecules on the cell surfaces of all nucleated cells. It interacts and stabilizes the tertiary structure of the major histocompatibility complex class 1 alphachain [5]. This protein is present in nearly all tissues of the body with exception of the red blood cells [6]. It is a member of the HLA where it is expressed in certain diseases conditions such as tumor in elevated concentration in the blood and detected in serum. WANCHU et al. [7] reported an elevated $\beta$-2microglobulin in HIV patients infected with tuberculosis unlike those with HIV alone. García-García et al. [8] reported that $\beta$-2-microglobulin (2$\beta \mathrm{M})$ level could be reduced in HCV infected individuals undergoing antiretroviral treatmentwhich means that a reduction in $\mathrm{HCV}$ infection must have led to the decrease in the $2 \mathrm{MG}$ concentration.

Co-infection of HBV with HIV are a public health concern with increasing incidence, their impact in the population and similarity in their epidemiological characteristics as well as similar mode of transmission [9-11]. HBV infection is considered opportunistic in HIV infected individuals due to a reduced immunity which makes HIV infected individuals becoming immune compromised thereby progressing the HBV infection to chronic hepatitis [9, 12-14]. $\mathrm{HBV}$ is usually more prevalent in HIV infected individuals than the general population $[9,15]$. HBV infections could be seen as chronic, acute, persistence or occult with different HBV markers detected by serological means. Though in advanced countries the use of molecular method of diagnosis is being used to detect HBV DNA of this is not done in the routine clinical laboratory in Nigeria. In some individuals, the DNA may be detected without the HBsAg which could be seen as occult infection [16]. Such individuals included those with HBV risk factors, hepatic carcinoma, chronic HBV carriers, HBV$\mathrm{HCV}$ co-infection, immunosuppressed and those with increase in hepatic enzymes and proteins like 2- $\beta$-microglobulin (cryptogenic cirrhosis). HBV/HIV coinfection have been reported to be as high as 10 to $20 \%$ in countries where HBV is either endemic or intermediate to high HBV cases. HBV and HIV coinfection leads to a higher morbidity and mortality rate as compared to HIV or HBV monoinfection [17]. MARIUKU et al. [17] reported a prevalence of HBV-HIV coinfection of $10.3 \%$ in Nairobi. Seroprevalence of HBV and HCV in Nasarawa state Nigeria have been reported among HIV positive individuals and 13.5\% were positive to HBV [18]. In cuba, MARITE et al. [9] reported a $30.4 \%$ prevalence among HIV positive individual.

Markers that have been used to measure the progression to hepatocellular carcinoma in HBV included AST, ALT and bilirubin levels however, 2 - $\beta$-microglobulin levels in serum might well measure more specific the progression to hepatocellular carcinoma since it is a tumor marker.

This cross sectional study aims to report the prevalence of HBV in HIV positive individuals as well as their progression to hepatocellular carcinoma using the 2- $\beta$-microglobulin concentration as a factor as well as monitor the levels of $2 \beta M$ concentration in those receiving ART. This is the first study to assay $2 \beta M$ in HBV-HIV coinfection in Nigeria and one of the few in sub-Saharan Africa.

\section{Materials and Methods}

\section{Patients and Control}

Blood samples $(n=435)$ were collected from individuals visiting different HIV screening centres across South West Nigeria around April to August 2012. All the participants provided written consent. The 435 subjects included 110 HIV positive individuals, 217 HIV and Hepatitis B virus (HBV) positive subjects and HBV positive (108) individuals. All the participants were screened for human papilloma virus, Hepatitis B and D viruses, tuberculosis, typhoid and malaria fever, observation for any sign of diarrhea by a clinician and anyone positive to any of these 
organisms/viruses or symptoms were excluded from the study. The HBV and HIV positive participants (mono-infected) alone served as control.

\section{Blood Processing}

Aseptically collected blood into sterile vacutaniers was immediately centrifuged and sera separated from whole blood and then stored in a $-200 C$ refrigerator before use. The Enzyme Linked Immunosrbent Assay (ELISA) was used to analyze all the sera. The sera were brought out of the refrigerator and allowed to attain room temperature. ELISA kits for HIV IgM and IgG, HPV IgM and IgG, tuberculosis ELISA, HCV ELISA, typhoid and malaria were used to screen for the exclusion criteria in the first instant. All kits were allowed to attain room temperature and test carried out as directed by the manufacturer (WKEA medical supplies, China). Absorbance was measured in a microplate reader (Thermomax, Molecular devices, USA) and cut-off calculated as directed by the manufacturer of the kits. The cut-off value is the value of the absorbance from where an absorbance may be regarded as positive and as well as negative. Any value of absorbance below the cutoff is regarded as negative while those above the cut-off are regarded as positive. Hepatitis B surface antigen (HBSAg) in HIV positive individuals was also screened for using the ELISA technique with Kits from Wkea Medical Supplies (China). Absorbance was measured with microplate reader (Thermomax, Molecular Devices, USA) at 450 optical density. Cut off was also calculated as directed by the kit manufacturer. Both cases and controls were screened for HBsAG. Monoinfected individuals were also identified. 2BM was screened for by using the quantitative ELISA technique, sera and ELISA kits were allowed to come to room temperature and the test carried out as described by the manufacturer. Optical density values were read at 450nm. Graphs and regression analysis of absorbance were carried out using the online myassays software.

\section{Results and Discussion}

Of the 110 monoinfected HIV positive individuals $($ mean $=12.222) 39$ (35.45\%) were males while 71 (64.55\%) were females. HIV+HBV with total number of participants as 217 (mean $=24.111$ ) had 86 (39.63\%) males and 131 (60.37\%) females, the 108 (mean $=12$ ) participants with HBV alone positive 41 (37.96\%) were males while 67 (62.04\%) were females (Table 1).There was no significant difference between the number of males and females participants though they were not matched. Sex and age of participants did not correlate with $2 \beta \mathrm{M}$ levels which support an earlier report by GARCIA-GARCIA et al. [8]. The absorbance of each of the samples increased as concentration of the $2 \beta M$ increased in each of the samples (Figure 1). This study reveals the increase in $2 \beta M$ levels in serum of HIV patients infected with HBV as compared to those infected with HIV and HBV alone respectively which has lower levels of $2 \beta \mathrm{M}$. The normal $2 \beta \mathrm{M}$ levels in healthy individuals which served as baseli-

Table 1. Descriptive statistics and characteristics of participants.

\begin{tabular}{|c|c|c|c|c|c|}
\hline Characteristics & HIV & HIV+HBV & HBV & $F$ & $p$ \\
\hline $\begin{array}{l}\text { Number of } \\
\text { Subjects }\end{array}$ & 110 & 217 & 108 & 2.861 & 0.079 \\
\hline $\begin{array}{l}\text { Number of } \\
\text { Males }\end{array}$ & 39 & 86 & 41 & & \\
\hline $\begin{array}{l}\text { Number of } \\
\text { Females }\end{array}$ & 71 & 131 & 67 & & \\
\hline Mean & 12.222 & 24.111 & 12 & & \\
\hline Median & 10 & 21 & 10 & & \\
\hline $\begin{array}{l}\text { Standard } \\
\text { Deviation }\end{array}$ & 8.800 & 20.833 & 9.927 & & \\
\hline $\begin{array}{l}\text { Conf. Interval } \\
(95 \%)\end{array}$ & 6.764 & 16.052 & 7.128 & & \\
\hline Standard Error & 2.933 & 6.961 & 3.091 & & \\
\hline Variance & 87.714 & 404.982 & 90.411 & & \\
\hline Correlation & 0.850 & 0.491 & 0.841 & & \\
\hline
\end{tabular}

Regression analysis and Analysis of variance: $R=0.887$, SE: 3.268 , Sig. of $F=0.0230$ 
Figure 1: Linear regression of $2 \beta \mathrm{M}$ concentration in HIV and HBV positive samples their and absorbance.

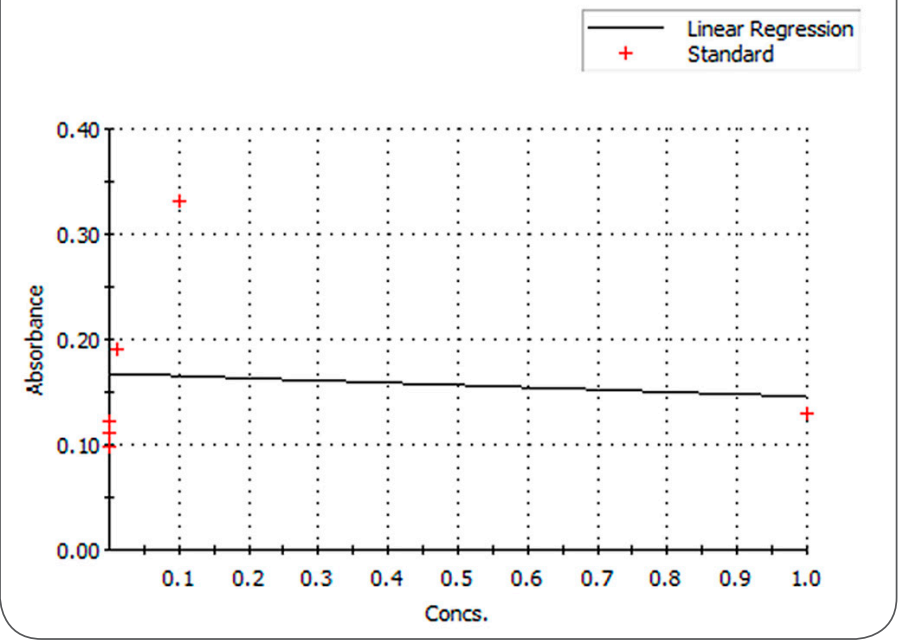

ne for this study is $2.6-4.5 \mu \mathrm{g} / \mathrm{ml}(\mathrm{Cl}=95 \%)$ (WKEA Medical Supplies, China). There have been increasing reports that some infections in HIV patients may lead to an elevated concentration of $2 \beta \mathrm{M}$ levels and some have implicated such increase with the development of hepatitis in HIV patients and also in HIV negative individuals [19, 20, 21, 9]. Though there have been reports of elevated $2 \beta \mathrm{M}$ in HIV patients [22, 23], 2BM in HIV patients gets higher with infections like HBV. These reports have it that $2 \beta M$ also correlate well with CD4 cell count and as such a good maker for monitoring disease progression in HIV infection especially those that could lead to tumour. However, recent reports using $2 \beta M$ as a marker to HBV infection in HIV patients and development to carcinoma are sparse. In a study, YEGANE et al. [21] reported an elevated level of $2 \beta M$ while monitoring chronic HBV which explains why this study included both HIV monoinfected patients and HBV monoinfected patients as controls in this study. The normal levels of $2 \beta \mathrm{M}$ was observed in $32(29.1 \%)$ individuals monoinfected with HIV while 45 (40.91\%) had high levels and the rest (30\%) had very high levels. This observation agrees with ELEFSINIOTIS et al. [5] which reports that there was an increase in $2 \beta \mathrm{M}$ during immune activation in the early phase of HIV infection before seroconversion and most of the individuals with high and very high levels of $2 \beta M$ are those in the early phase of infection. The $2 \beta M$ levels were in the normal range in $37(17.1 \%)$ individuals co-infected with HIV and HBV and 63 (57.3\%) had high levels while the rest $25.6 \%$ had very high levels. The increase in the number of individuals with very high level of $2 \beta M$ in HIV/HBV coinfected individuals as against HIV monoinfection is as a result of the involvement of HBV which may have elevated the immune activation more than that of moninfection with HIV. Individuals monoinfected with HBV had 15 (13.89\%) individuals with normal levels of 2BM while 63 (58.33\%) had high levels and the rest (27.78\%) had very high levels of $2 \beta M$. The $x^{2}\left(x^{2}=69.89 ; p\right.$-value $\left.=<0.0000001\right)$ revealed no significant relationship between the 3 variables and hence $x^{2}$ was rejected (Table 2 ). This means that more HIV/HBV coinfected patients are in

Table 2. The number of individuals with different concentration of $2 \beta \mathrm{M}$ in all participants.

\begin{tabular}{|c|c|c|c|c|}
\hline $2 \beta M$ conc. & HIV & $\mathrm{HIV}+\mathrm{HBV}$ & HBV & Total \\
\hline $0-2$ & $\begin{array}{l}10(66.70) \\
(9.10)\end{array}$ & $\begin{array}{l}0(0) \\
(0)\end{array}$ & $\begin{array}{l}5(33.30) \\
(4.60)\end{array}$ & 15 \\
\hline $3-5$ & $\begin{array}{l}22(64.70) \\
9(20)\end{array}$ & $\begin{array}{l}2(5.90) \\
(0.90)\end{array}$ & $\begin{array}{l}10(29.40) \\
(9.30)\end{array}$ & 34 \\
\hline $6-7$ & $\begin{array}{l}20(26 \%) \\
(18.20)\end{array}$ & $\begin{array}{l}35(45.50) \\
(16.10)\end{array}$ & $\begin{array}{l}22(28.60) \\
(20.40)\end{array}$ & 77 \\
\hline $8-10$ & $\begin{array}{l}25(21.70) \\
(22.70)\end{array}$ & $\begin{array}{l}61(53) \\
(28.10)\end{array}$ & $\begin{array}{l}29(25.20) \\
(26.90)\end{array}$ & 115 \\
\hline $11-13$ & $\begin{array}{l}10(15.40) \\
(9.10)\end{array}$ & $\begin{array}{l}43(66.20) \\
(19.80)\end{array}$ & $\begin{array}{l}12(18.50) \\
(11.10)\end{array}$ & 65 \\
\hline $14-16$ & $\begin{array}{l}15(21.70) \\
(13.60)\end{array}$ & $\begin{array}{l}36(52.20) \\
(16.60)\end{array}$ & $\begin{array}{l}18(26.10) \\
(16.70)\end{array}$ & 69 \\
\hline $17-19$ & $\begin{array}{l}5(15.20) \\
(4.50)\end{array}$ & $\begin{array}{l}21(63.60) \\
(9.70)\end{array}$ & $\begin{array}{l}7(21.20) \\
(6.50)\end{array}$ & 33 \\
\hline $20-22$ & $\begin{array}{l}2(11.80) \\
(1.80)\end{array}$ & $\begin{array}{l}11(64.70) \\
(5.10)\end{array}$ & $\begin{array}{l}4(23.50) \\
(3.70)\end{array}$ & 17 \\
\hline $23-25$ & $\begin{array}{l}1(10) \\
(0.90)\end{array}$ & $\begin{array}{l}8(80) \\
(3.70)\end{array}$ & $\begin{array}{l}1(10) \\
(0.90)\end{array}$ & 10 \\
\hline Total & $\begin{array}{l}110 \\
(25.30)\end{array}$ & $\begin{array}{l}217 \\
(49.90)\end{array}$ & $\begin{array}{l}108 \\
(24.80\end{array}$ & 435 \\
\hline & & \multicolumn{3}{|c|}{$x=69.89 ; p$-value $=<0.0000001$} \\
\hline
\end{tabular}


the very high level of $2 \beta \mathrm{M}$ and also in the high level as defined by this study. This observation supports a report by GARCIA-GARCIA et al. (2003) which reported an elevated levels of $2 \beta \mathrm{M}$ in HIV/HCV coinfected patients. The odds of having high concentration of $2 \beta M$ in $\mathrm{HIV}+\mathrm{HBV}$ infected individuals when both controls were added together (Table 3 ) was lesser than when the controls were separated (Table 4 and 5). This confirms that the immune activation in HIV/ HBV patients was more intense with regards to the concentration of $2 \beta \mathrm{M}$ as $2 \beta \mathrm{M}$ is a product of immune activation and has also helped in transferring the virus to the hepatocytes with likely progression to carcinoma. It has been reported that as part of HLA class I complex, $2 \beta M$ is responsible in the transport of viral antigens to the hepatocyte surfaces [21]. MARIANo et al. (2000) reported that an increase in concentration of $2 \beta \mathrm{M}$ in $\mathrm{HCV}$ infected individuals correlated with hepatocellular carcinoma, a report this study agrees with and suggests that HIV/HBV co-infected individuals with high levels of $2 \beta \mathrm{M}$ are at a high risk of developing carcinoma.

Table 3. Odds of concentration of co-infection of HIV and HBV using HIV moninfection and HBV monoinfection together as control.

\begin{tabular}{|c|c|c|c|c|}
\hline $2 \beta M$ conc. & HBV+HIV & $\begin{array}{l}\text { HIV and HBV } \\
\text { Controls }\end{array}$ & Total & Odds \\
\hline 0 & 0 & 15 & 15 & 0 \\
\hline 3 & 2 & 32 & 34 & 0.06 \\
\hline 6 & 35 & 42 & 77 & 0.83 \\
\hline 9 & 61 & 54 & 115 & 1.13 \\
\hline 12 & 43 & 22 & 65 & 1.95 \\
\hline 15 & 36 & 33 & 69 & 1.09 \\
\hline 18 & 21 & 12 & 33 & 1.75 \\
\hline 21 & 11 & 6 & 17 & 1.83 \\
\hline 24 & 8 & 2 & 10 & 4 \\
\hline Total & 217 & 218 & 435 & \\
\hline
\end{tabular}

Extended Mantel-Haenszel chi square for linear trend=33.64 $p$-value (1 degree of freedom $)=<0.0000001$
Table 4. Odds of concentration of co-infection of HIV and HBV using only HIV moninfection toas control.

\begin{tabular}{|c|c|c|c|c|}
\hline $2 \beta M$ conc. & HBV+HIV & $\begin{array}{l}\text { HIV only } \\
\text { (Control) }\end{array}$ & Total & Odds \\
\hline 0 & 0 & 10 & 10 & 0 \\
\hline 3 & 2 & 22 & 24 & 0.09 \\
\hline 6 & 35 & 20 & 55 & 1.75 \\
\hline 9 & 61 & 25 & 86 & 2.44 \\
\hline 12 & 43 & 10 & 53 & 4.3 \\
\hline 15 & 36 & 15 & 51 & 2.4 \\
\hline 18 & 21 & 5 & 26 & 4.2 \\
\hline 21 & 11 & 2 & 13 & 5.5 \\
\hline 24 & 8 & 1 & 9 & 8 \\
\hline Total & 217 & 110 & 327 & \\
\hline
\end{tabular}

Extended Mantel-Haenszel chi square for linear trend=36.21 $p$-value $(1$ degree of freedom $)=<0.0000001$

Table 5. Odds of concentration of co-infection of HIV and HBV using HBV monoinfection as control

\begin{tabular}{|c|c|c|c|c|}
\hline 23M conc. & HBV+HIV & $\begin{array}{c}\text { HBV only } \\
\text { (Control) }\end{array}$ & Total & Odds \\
\hline 0 & 0 & 5 & 5 & 0 \\
\hline 3 & 2 & 10 & 12 & 0.2 \\
\hline 6 & 35 & 22 & 57 & 1.59 \\
\hline 9 & 61 & 29 & 90 & 2.1 \\
\hline 12 & 43 & 12 & 55 & 3.58 \\
\hline 15 & 36 & 18 & 54 & 2 \\
\hline 18 & 21 & 7 & 28 & 3 \\
\hline 21 & 11 & 4 & 15 & 2.75 \\
\hline 24 & 8 & 1 & 9 & 8 \\
\hline Total & 217 & 108 & 325 & \\
\hline
\end{tabular}

Extended Mantel-Haenszel chi square for linear trend=12.96 $p$-value $(1$ degree of freedom $)=0.0003238$ 


\section{Conclusion}

This study suggests that HIV/HBV patients are at higher risk of developing hepatocellular carcinoma than those monoinfected using $2 \mathrm{MG}$ as a marker and this study is the first to report the use of $2 \beta \mathrm{M}$ as a marker of HBV hepatocellular carcinoma in $\mathrm{Ni}$ geria. Hence in co-infection with HBV efforts must be made to monitor development to hepatocellular carcinoma using more specific markers like $2 \beta \mathrm{M}$.

\section{References}

- Jaroszewicz J, Riberger T, Meyer-Olson D, Mauss S, Vogel M, Ingiliz P, Payer BA, Stoll M, Manss MP, Schmidt RE, Flisiak R, Wedemeyer H, Peck-Radosavijevic M, Rockstroh J and Cornberg M. Hepatitis B surface antigen concentration in patients with HIV/HBV co-infection. PLO one 2012, 7 (8) e43143; 1-7.

- European Association for the study of Liver EASL, Clinical Practice Guidelines, management of chronic hepatitis B. J of hepato/ 2012, 57; 157-185.

- Cornberg M, Jaroszewicz J, Manss MP, Wedemeyer H. Treatment of chronic hepatitis B. Minerva Gastroenterol. Dietol 2010, 56; 451-465.

- Rheeder P, Nel L, Meeuwes F, Van SM and Meyer PWA. Beta2 microglobulin as a predictor of peripheral arterial disease in diabetes: the effect of estimated glomerular filtration. JEMDSA 2012, 17(3):141-144

- Elefsiniotis IS, Scarmeas N, Glynou I, Pantazis KD, Kada H, Mavrogiannis C. Serum beta 2-microglobulin levels in hepatitis B e antigen-negative chronic hepatitis B patients under long term lamivudine monotherapy: Relationship with virological breakthrough. Can J Gastroenterol. 2004, 18(5): 307-313.

- Akdogan M, Senturk H, Mert A, Tabak F and Ozbay G. Acute exacerbation during interferon alfa treatment of chronic hepatitis hepatitis $B$; frequency and relation to serum $\beta-2$ microglobulin levels. J. Gastroenterol. 2003, 38; 464-470

- Wanch A, Dong Y, Sethi S, Myneedu VP, Nadas A, Liu Z, Belisle $J$ and Laal S. Biomarkers for Clinical and Incipient Tuberculosis: Performance in a TB-Endemic Country. PLO One 2008, 3 (4) DOI: 10.1371/journal.pone.0002071
- Garcia-Garcia JA, Mira JA, Fernàndez-Rivera J, Ramos AJ, Vargas J, Macias J and Pineda JA Influence of hepatitis C virus coinfection on failure of HIV-infected patients receiving highly active antiretroviral therapy to achieve normal serum B2microglobulin levels. Euro. J of Clin Microbiol and Infect. Dis. 2003, 22 (3), 194-196.

- Bello M, Caridad M, Rodriguez LA, Sariego S, Verdasquera D, Vincent M, Guti冈rrez A and Sànchez M. Occult hepatitis B in Cuban HIV patients. Medicc Rev. 2001, 13 (2); 32-37.

- Lukhwareni A, Burnett RJ, Selabe SG, Mzilleni MO and Mphahlele MJ. Increased detection of HBV DNA in HBsAg-antigen positive and HBsAg-negative South AfricanHIV/AIDS patients enrolling for highly active antiretroviral therapy at a tertiary hospital. J. of Med. Virol. 2009, 81 (3); 406-12.

- Fabris P, Blasin MR, Giordani MT, Bernado L, Menini V,Carloto A et al. Impact of occult HBV infection in HIV/HCV coinfected patients. HBV-DNA detection in liver specimens and in serum samples. Curr. HIV Res. 2008, 6 (2): 173-9.

- Burnett RJ, François G, Kow MC, Laroux-Roels G, Meheus A, Hoosen AA et al. Hepatitis B virus and Human Immune Deficiency co-infection in sub-Saharan Africa. A call for further investigation. Liver int. 2005, 25 (2): 201-13.

- Modi AA and Field JJ. Viral hepatitis and HIV in Africa. AIDS Rev. 2007, (1): 25-39.

- Mphahelele MJ. Impact of HIV co-infection on hepatitis B prevention and control. A view from sub-Saharan Africa. SAJEI 2008, 23 (1) 14-8

- Fabris P, Blasin MP, Giordani MT, Berando L, Menini V, Carloto A et al. (2008) Impact of occult HBV infection in HIV/HCV coinfected patients. HBV-DNA detection in liver specimens and serum samples. Curr. HIV Res. 2008, 6 (2):173-9.

- Torbensen M, Thomas DL. Occult hepatitis B infection. Lancet infect. Dis. 2002, 2 (8) 479-86.

- Muriuki BM, Gicheru MM, Wachira D, Nyamache AK and Khamad SA. Prevalence of hepatitis B and C viral co-infections among HIV1 infected individuals in Nairobi, Kenya. BMC Res. Notes 2013, 6:363. doi:10.1186/1756-0500-6-363.

- Akyala IA, Obande G, Ishaleku D. Seroprevalence of hepatitis $B$ and C co-infection among cohort seropositive HIV patients accessing healthcare in Nasarawa state, North Central Nigeria. Brit. J. of Psyco. Res. 2013, 1 (1) 15-24.

- Amodio P, Gatta A, and Ruol A. Beta 2-microglobulin concentration in plasma and production in liver cirrhosis. J. Clin. Chem. Clin. Biochem. 1984, 22, 147-151. 
- Akdogan M, Senturk H, Mert A, Tabak F and Ozbay G. Acute exacerbation during interferon alpha treatment of chronic hepatitis B: frequency and relation to serum $\beta$ 2-microglobulin levels. J. Gastroenterol. 2003, 38, 465-470.

- Yegane S, Revanli M and Taneli F. The role of $\beta$ 2-microglobulin levels in monitoring chronic hepatitis B. Tohoku J. Exp. Med. 2004, 203, 53-57.

- Hofmann B, Wang Yx, Cumberland Wg, Detels R, Bozorgmehri $M$. Serum beta 2 microglobulin level increases in HIV infection: relation to seroconversion, CD4 T-cell fall and prognosis. AIDS. 1990, 4(3):207-14

- Wanchu A, Arora S, Bhatnagar A, Sud A, Bambery P, Singh S. Beta2 microglobulin as a surrogate marker for HIV infection: good correlation with CD4 counts. Indian J Pathol Microbiol. 2004, 47(2):298-301

\section{Comment on this article:}

\section{(f) $[$ in $8+\mathbf{S}$.}

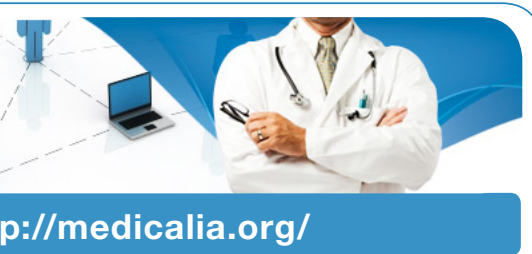

Where Doctors exchange clinical experiences, review their cases and share clinical knowledge. You can also access lots of medical publications for free. Join Now!

\section{Publish with iMedPub}

\section{http://www.imed.pub}

International Archives of Medicine is an open access journal publishing articles encompassing all aspects of medical science and clinical practice. IAM is considered a megajournal with independent sections on all areas of medicine. IAM is a really international journal with authors and board members from all around the world. The journal is widely indexed and classified Q1 in category Medicine. 